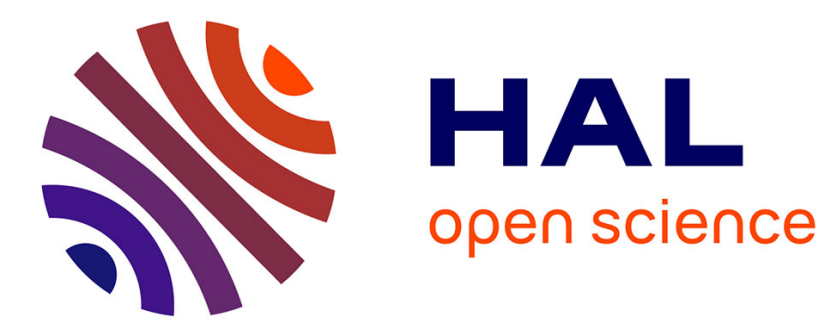

\title{
Which securities for workers in times of crisis?
}

Olivier Leclerc

\section{To cite this version:}

Olivier Leclerc. Which securities for workers in times of crisis?: Challenges and perspectives. European labour law journal, 2014, 5 (3-4), pp.410-416. 10.1177/201395251400500314 . halshs-01089602

\section{HAL Id: halshs-01089602 \\ https://shs.hal.science/halshs-01089602}

Submitted on 31 Jan 2020

HAL is a multi-disciplinary open access archive for the deposit and dissemination of scientific research documents, whether they are published or not. The documents may come from teaching and research institutions in France or abroad, or from public or private research centers.
L'archive ouverte pluridisciplinaire HAL, est destinée au dépôt et à la diffusion de documents scientifiques de niveau recherche, publiés ou non, émanant des établissements d'enseignement et de recherche français ou étrangers, des laboratoires publics ou privés. 


\title{
Which securities for workers in times of crisis? Challenges and perspectives
}

\author{
Olivier LECLERC*
}

\author{
Published in European Labour Law \\ Journal, vol. 5, n $^{\circ} 3-4$, 2014, pp. 410-
}

416.

\begin{abstract}
This article concludes the special issue Which securities for workers in times of crisis? It focuses on three aspects. First, it stresses the need for a reappraisal of the conceptual apparatus of labour law. Second, it discusses some of the tensions in the relationship between labour law reform and economic crisis. It suggests that the notion of crisis is not helpful in understanding the current changes to labour law systems. Finally, the article highlights some perspectives offered by the special issue, with special attention to the notion of risk as an alternative paradigm.
\end{abstract}

\section{Concepts of labour law in crisis}

Various comparative works have been devoted to labour law and economic crisis (Moreau 2011; Loy 2011; Escande-Varniol, Laulom, Mazuyer and Vielle 2012; Lokiec and Robin-Olivier 2012). The articles published in this special issue continue along this route, observing with a critical eye. The articles are analytically ordered around four

* Researcher at CNRS (CERCRID), University of Lyon, University Jean Monnet (Saint-Etienne), France. E-mail: olivier.leclerc@univ-st-etienne.fr 
conventional wisdoms and challenges to such. An alternative view is then offered, arguably richer. First, the legal answers to the ongoing economic crisis are often presented as naturally contingent. Contrary to that commonplace idea it can be seen, in fact, that the current transformations of national labour laws and social security systems are profound, structural, and long-lasting. Although many legislative interventions refer explicitly to the economic crisis as a justification and rationale, the articles in this issue examine how, instead, they take place within the context of long-term developments that started long ago and hardly relate exclusively to the financial crisis of 2008 and its aftermath. The decentralisation of collective bargaining, the weakening of the contract of employment in the sense of a set of rights that cannot be amended without the employee's individual consent, the individualisation of labour relations - these developments surely cannot be described as new or temporary. No one would imagine them reversible once the economy recovers. Second, the special issue challenges the relevancy of the insiders/outsiders distinction. Though the distinction might be given a slightly broader scope here than in the seminal analysis of Doeringer and Piore (1971), the contributors to this special issue convincingly demonstrate that vulnerability in the labour market does not afflict only outsiders but is distributed throughout a wide range of positions in the labour market, including those of public sector workers. Third, the papers undermine the confidence placed in flexicurity as a relevant approach to achieve an efficient functioning of labour markets. Although the flexibility end of the scale has been illustrated on many occasions in recent years, the security part remains comparatively scarce. Notwithstanding the continued adherence by the European Commission and Member States to flexicurity, one may legitimately question its ability to provide effective 
protection for workers in times of economic crisis. Amongst other things, the willingness of Member States to afford the costs of security for workers must be viewed with particular caution. More generally, the possibility to foster security through training and the portability of rights is doubtful in a context of profound insecurity of work, due to unemployment, short-term contracts, and an increasing number of specific contractual arrangements for younger and older workers. Fourth, more surprisingly, while fundamental rights are commonly viewed as providing workers with a set of solid and robust rights, this special issue highlights the ambivalence of this claim. Moizard (in this issue) points to the tendency of States to give priority to the economy over social rights and suggests that this may also lead States to hesitate to engage further in the protection of social rights through international organizations, such as the International Labour Organization (ILO).

In addition to affirming the urgent need for better protection for workers in times of crisis, the articles also question the concepts of labour law. Are these concepts relevant in considering the current changes to national labour law? At first glance, the answer will probably be negative. One is confronted with an unsatisfactory impression of disenchantment and lack of inventiveness. Reading the articles of this special issue leaves one with the feeling that our conceptual framework does not fit well with present times. The legal categories and distinctions do not seem to be in line with the structures of the labour market. Indeed, labour law is organized in most European countries along divisions such as labour law / public employment, permanent contracts / fixed-term contracts, contract of employment / independent work, and legal work / undeclared work. 
It is commonplace to claim that the first term offers stronger protection for workers (who will, in return, accept their employer's orders). In contrast, independent workers have to face the risks and reap the benefits of their own economic activity. The changes in national legal systems, whether in labour law or in relation to self-employed workers, tend to blur these distinctions, that is, if ever they were clear cut (e.g. Leclerc et al. 2010; Prassl 2013). In that context, relying on flexicurity seems much more of a mantra than an analytical insight. Hence, the impression of frustration we might feel when considering the evolution of national labour law in recent years probably arises not only from the damaged state of economic and social conditions but also from an intellectual dissatisfaction. To borrow Otto Kahn-Freund's (1966) words, do we need a new 'alphabet of concepts'? Or does the conceptual framework of labour law still offer food for thought? Two central notions of labour law would certainly benefit from conceptual reshaping. One is the notion of worker, which should be enlarged to encompass several forms of work (Freedland 2003), or which could be substituted by the notion of the person themselves as a source of protection (Supiot 2001). Another conceptual initiative is required on the notion of the firm. At stake is the capacity to identify the employer in a more realistic way, in a situation where firms tend to be embedded in a wide variety of network-like relations and where the identification of a single source of power is no longer possible (Peskine 2008). Further, we need to find ways to integrate social interests into the goals of a firm. Corporate governance, though inescapable, does not suffice. Relying on ISO Standard 26000 is not enough either. Some suggest the design of new legal structures for firms, whose objectives would be equally economic, social and environmental (Segrestin and Hatchuel 2012). Social and environmental sustainability 
could then override short-term financial profitability.

\section{The economic crisis - a driving force for labour law reform?}

The articles published in this special issue tackle the evolution of labour law in times of crisis in the light of several national legal systems. Therefore, the relationship between crisis and reform is a central question. Recent laws in many countries have been designed explicitly as answers to the economic crisis. In these circumstances, national labour law systems are urged to adapt to the new economic situation. Nevertheless, the relationship between labour law and crisis is far from simple, just as the notion of 'adaptation' of labour law is not unambiguous. Imputation of a specific change in labour law to economic crisis often remains equivocal (Jeammaud 1997). Though one can underline the fact that a specific reform is concomitant with the economic crisis, establishing a causal link between the two of them is another step. It is sometimes hard to say whether labour law is affected in the name of crisis or by the crisis (Jeammaud 1997, 117).

Do we really need a reference to the economic crisis to get a handle on the recent labour law reforms in Europe? Focusing on the crisis is arguably not as helpful as it seems at first glance. The etymology of the very notion of 'crisis' refers to a decisive moment in an uncertain process that will enable diagnosis and possibly recovery. The word was initially coined in the domain of health and medical science. A crisis is the point in time when the pathology, which was formerly concealed, is discovered and when the physician offers a diagnosis. The articles published in this special issue show instead that many changes in national labour law systems are the product of long-term developments. It would then be 
too sketchy to think of the 2008 economic crisis as a turning point as many changes in legal systems were already well underway. Rather, economic crisis has always been a ‘travelling companion’ of labour law (Palomeque López 1984). Hence, focusing on crisis and on adaptation to the crisis gives a false impression that we are experiencing a shortterm situation and does not help in understanding the nature of the current changes. Thinking of labour law and economic crisis focuses a specific attention on the maladjustment between the economic situation and labour law and encourages labour law to evolve in order to 'compensate' this mismatch. It is more interesting to pose the question the other way round. What is labour law adapted to? To what forms of economic activities is labour law adjusted? Put that way, the question helps to think of current changes in national labour law systems not as a temporary phenomenon related to an economic crisis but as a consequence of deeper changes in capitalism, such as increasing movements of goods and capital, transnational undertakings, decentralisation of productive activities, fragmentation of undertakings, and competition between workers (e.g. Arthurs 2001; Deakin and Wilkinson 2005; Moreau 2006; Rigaux 2009). Further, not all undertakings, by far, are transnational. In many European countries, the majority of the labour force is employed in small firms. Emphasising adaptation to the economic crisis favours a focus on transnational undertakings, while the dynamic interplay between the local and the global also requires deeper understanding. Finally, the crisis rhetoric erases the differences between countries as regards their development. In fact, countries are very differently affected by the evolution of capitalism and by globalization, depending on factors such as their industrial development, the extent to which agriculture remains labour intensive, their inclusion in a regional free-trade agreement, etc. (Olivié 
2005).

Furthermore, the very idea of 'crisis' does not help in understanding the changes in social policy (Bruun and Hepple 2009). Indeed, the idea of 'crisis' presupposes a specific temporality: crisis is inseparable from a conception and an experience of time (Revault d'Allonnes 2012). Crisis relates to a specific period of time and crystallizes in a critical moment where choices are at stake. In that sense, crisis are moments, inescapable passages in a process. They are fully compatible with the idea of progress. Reading the articles published in this special issue leaves one with a very different feeling. The recent evolutions in labour law do not seem to be supported by any idea of progress in labour law. Worse, it seems that there is nothing to be decided, as if the evolution of labour law is beyond the grasp of social policy. The paradox is that European countries are reforming constantly in the name of modernization and adaptation of labour law and, at the same time, they give the impression of being almost entirely deprived of the capacity to pursue an effective social policy. Labour law reform seems to be one of the few policy instruments available to governments in the eurozone with which to reassure the financial markets and to avoid the downgrading of their sovereign debt by the credit rating agencies. In that sense, labour market reform seems to work as a signal to the financial markets of the willingness of individual States to act positively for the sake of their economy. In the meantime, the weakness of the social agenda of the European Commission together with the subordination of social rights to economic freedoms promoted by the European Court of Justice makes it hard to see how European action will substitute more effectively for the social policy of the Member States. In that respect, the 
articles published in this special issue share the view that labour law should remain an instrument for active social policy and not be subordinated to economic mechanisms, with the sole injunction of 'adaptation' as its horizon (see also Countouris and Freedland 2013). Thinking of the changes to labour law in relation to the economic crisis is certainly not the surest way to achieve this project.

\section{Risk - an alternative paradigm?}

To the extent that it challenges conventional wisdoms, this special issue calls for closer attention to be paid to the changes in national labour law. At the same time, the special issue suggests the need to seek better protections for workers outside the scope of flexicurity and fundamental rights. What solutions do we then have at hand to foster security for workers in times of economic crisis? The papers suggest some, although none of them are likely to be implemented easily. No doubt that collective action remains a possible source of resistance for workers. The development of collective bargaining is another possible solution, provided that the conditions are met for a well-balanced dialogue between employers and workers. The progress of vulnerability at work makes this less likely to happen, insofar as the individualisation of labour relations does not encourage unionisation and the designation of worker representatives. Giving teeth to the collective complaints mechanism for the European Social Charter is another possibility (De Schutter 2010). Finally, an important protection factor for workers comes from social security systems.

Stepping back from these perspectives, this special issue presents risk as a proper 
conceptual alternative. This assertion deserves some attention. As Loi (in this issue) points out, the concept of flexicurity supposes a false parallel between flexibility (i.e. the economic dimension of the markets and of the firm) and security (i.e. the legal dimension and a condition of the individual). Hence, she asserts, 'the opposite concept of security is not flexibility but risk’. Broadly speaking, labour law is conceptualized as a tool for rationalizing, categorizing and managing social risks. Thinking that way enables one to identify specific sets of workers exposed to a given risk or to a certain level of risk. The vulnerability of these groups calls for targeted action in order to prevent the risk occurring or to mitigate its consequences. As such, the notion of risk is certainly not a newcomer to legal analysis. The role it plays in social security systems is eminent and well-known. Nevertheless, its usefulness in analysing the changes to labour law systems is also obvious, as economic crisis might be seen as a catalyst for a greater diffusion of risks. The current national reforms allocate risks in a certain way. They tend to shift the burden of risks to the workers or, at least, to some categories of workers, such as younger workers and unemployed people. Nonetheless, relying on risk as a 'new paradigm' leaves certain questions open. How far can we analyse labour law through the prism of risks? Strictly speaking, the notion of risk implies that circumstances are foreseeable. Thus it is closely related to the concept of probability (Millet 2001). For that reason, the notion of risk first appeared in legal terms in insurance law. Only the events whose probability is known are likely to be insured. The perception and analysis of risk sets in motion a prevention and anticipation process. For instance, employers are compelled to prevent the risks to health and safety of workers. This characteristic of risk also points to its limits. What if the probability of a particular hazard to workers is unknown or cannot be known? 
A precautionary approach seems to be a necessary complement to prevention. Further, relying on the paradigm of risk raises questions for the conceptualisation of workers as a

group. How can we constitute a set of workers facing the same risks? Can a group of workers facing the same risk constitute a bargaining unit? As a redistributive process, risk management also defines the scope of solidarity. Hence, the price for relying on the paradigm of risk might very well be a fragmentation of the overall workforce. Finally, the special issue encourages the search for better ways to reconcile the effective protection of workers against a variety of risks with the preservation of solidarity in the workforce.

\section{References}

Arthurs, Harry, "Reinventing Labor Law For The Global Economy: The Benjamin Aaron Lecture”, Berkeley Journal of Employment \& Labor Law, Vol. 22, 2001, pp. 271294.

Bruun, Niklas and Hepple, Bob, "Economic Policy and Labour Law”, in Hepple, B. and Veneziani, B. (eds.), The Transformation of Labour Law in Europe. A comparative study of 15 countries 1945-2004, Hart Publishing, Oxford, Portland, 2009.

Countouris, Nicola and Freedland, Mark (eds.), Resocialising Europe in a Time of Crisis, Cambridge University Press, Cambridge, 2013.

De Schutter, Olivier (ed.), The European Social Charter: A social constitution for Europe, Bruylant, Brussels, 2010.

Deakin, Simon and Wilkinson, Frank, The Law of the Labour Market. Industrialization, Employment, and Legal Evolution, Oxford University Press, Oxford, 2005.

Doeringer, Peter B. and Piore, Michael J., Internal Labor Markets and Manpower 
Adjustment, D.C. Heath and Company, New York, 1971.

Escande-Varniol, Marie-Cécile, Laulom, Sylvaine, Mazuyer, Emmanuelle and Vielle, Pascale (eds.), Quel droit social dans une Europe en crise?, Larcier, Brussels, 2012.

Freedland, Mark, The Personal Employment Contract, Oxford University Press, Oxford, 2003.

Jeammaud, Antoine, “Crise et relations du travail”, Droit de la crise, crise du droit?, PUF, Paris, 1997, pp. 91-128.

Kahn-Freund, Otto, “The Personal Scope of English Labour Law: 'Servant', 'Employee’, ‘Workman’”, Rivista di diritto del lavoro, 1966, pp. 508-524.

Leclerc, Olivier, Guamán Hernández, Adoración, Martelloni, Federico and Pasquier, Thomas, "La dépendance économique en droit du travail: éclairages en droit français et en droit compare”, Revue de droit du travail, No 2, 2010, pp. 83-90 and No 3, 2010, pp. 149-154.

Lokiec, Pascal and Robin-Olivier, Sophie (eds.), Special Issue “Les réactions du droit du travail à la crise”, Droit ouvrier, No 763, 2012.

Loy, Gianni (ed.), Diritto del lavoro e crisi economica, Ediesse, Rome, 2011.

Millet, Florence, La notion de risque et ses fonctions en droit privé, LGDJ, Paris, 2001.

Moreau, Marie-Ange, Normes sociales, droit du travail et mondialisation, Dalloz, Paris, 2006.

Moreau, Marie-Ange (ed.), with assistance from Iryna Ulasiuk, Before and after the economic crisis. What Implications for the 'European Social Model'?, Edward Elgar Publishing, Cheltenham, 2011.

Olivié, Iliana, Las Crisis de la Globalización. Marco teórico y estudio de los casos de 
México y Corea del Sur, Consejo Económico y Social, Madrid, 2005.

Palomeque López, Manuel Carlos, “Un compañero de viaje histórico del Derecho del Trabajo: la crísis económica”, Revista de política social, No 143, 1984, p. 15.

Peskine, Elsa, Réseaux d'entreprises et droit du travail, LGDJ, "Bibliothèque de droit social”, Paris, 2008.

Prassl, Jeremias, "Dismantling the Contract of Employment? The new Employee Shareholder Status in the United Kingdom”, European Labour Law Network Working Paper Series, 1/2013.

Revault d'Allonnes, Myriam, La crise sans fin, Le Seuil, “La couleur des idées”, Paris, 2012.

Rigaux, Marc, Droit du travail ou droit de la concurrence sociale? Essai sur un droit de la dignité de l'Homme au travail (re)mis en cause, Bruylant, Brussels, 2009.

Segrestin, Blanche and Hatchuel, Armand, Refonder l'entreprise, Le Seuil, "La République des idées”, Paris, 2012.

Supiot, Alain, Beyond Employment. Changes in Work and the Future of Labour Law in Europe, Oxford University Press, Oxford, 2001. 